\title{
Vakhtang I Gorgasali (r. 447-522) as a Christian Monarch in Georgia: His Depiction in the Life of Kartli
}

In antiquity, the Caucasus was located between two empires with long-lasting conflicts of interest: Rome and Persia. ${ }^{1}$ In the view of some late Roman emperors, the Persians barred the path to the East and threatened the eastern part of the empire by their westward expansion. ${ }^{2}$ From a Persian perspective, the Romans blocked the path to expansion and resurgence of their old empire. ${ }^{3}$ This complicated and enduring conflict dragged on over the course of several centuries into late antiquity. ${ }^{4}$ It included military confrontation with alternating victories and defeats. ${ }^{5}$

As the Persians and Romans fiercely battled over hegemony in the eastern Mediterranean, the Caucasus attained strategic importance as one of the frontiers between these two empires. The major powers of late antiquity both wanted to secure their own spheres of influence in the region, relying in part on expansive political power and partly on the persuasive force of their respective religious traditions. ${ }^{6}$

1 Klaus Schippmann, Grundzüge der Geschichte des sasanidischen Reiches, Darmstadt 1990; Josef Wiesehöfer, Das antike Persien. Von 550 v.Chr. bis 650 n.Chr., Düsseldorf/Zürich 1998.

2 James Howard-Johnston, The Sasanian's Strategic Dilemma, in: Henning Börm, Josef Wiesehöfer (ed.), Commutatio et contentio. Studies in the Late Roman, Sasanian and Early Islamic Near East in Memory of Zeev Rubin, Düsseldorf 2010, 37-70; id., The Grand Strategy of the Sasanian Empire, in Carsten Binder, Henning Börm, Andreas Luther (ed.), Diwan, Studies in the History and Culture of the Ancient Near East and the Eastern Mediterranean / Untersuchungen zu Geschichte und Kultur des Nahen Ostens und des östlichen Mittelmeerraumes im Altertum. Festschrift für Josef Wiesehöfer zum 65. Geburtstag, Duisburg 2016, 591-613.

3 Roger C. Blockley, East Roman Foreign Policy. Formation and Conduct from Diocletian to Anastasius (ACRA: Classical and Medieval Texts, Papers and Monographs 30), Leeds 1992.

4 James Howard-Johnston, East Rome, Sasanian Persia and the End of Antiquity. Historiographical and Historical Studies (Variorum Collected Studies 848), Aldershot 2006; Henning Börm, Prokop und die Perser. Untersuchungen zu den römisch-sasanidischen Kontakten in der ausgehenden Spätantike (Oriens et Occidens 16), Stuttgart 2007.

5 Edward Dabrowa (ed.), The Roman and Byzantine Army in the east. Proceedings of a Colloquium held at the Jagellonian University, Kraków in September 1992, Kraków 1994; Geoffrey B. Greatrex, Rome and Persia at War, 502-532, Leeds 1998.

6 Udo Reinhold Jeck, Die lautlose Invasion. Zur Auseinandersetzung griechischer Philosophen mit dem persischen Mythos, in: Rolf Elberfeld (ed.), Philosophiegeschichtsschreibung in globaler Perspektive (Deutsches Jahrbuch Philosophie 9), Hamburg 2017, 253-277. 
While the Persians tried to establish a form of Zoroastrianism in the Caucasus, ${ }^{7}$ Christianity, supported by Constantine I, also penetrated the region. ${ }^{8}$

During these political and religious conflicts, the monarchs of Georgia managed to, more or less successfully, preserve a certain amount of independence through careful manoeuvring. The Georgian ruling classes staunchly opposed both the expansive Persian imperialism and their religious encroachments through military means. They banked on Byzantium and the late Roman/Byzantine Christianity which ultimately prevailed in Georgia.

The events of this formative period in Georgian history are very difficult to reconstruct. Later sources offer at least insight into the reception of this time in the Georgian tradition. This study will focus on the representation of Georgian King Vakhtang I Gorgasali in the Life of Vakhtang Gorgasali embedded within the Georgian royal chronicles known as the Life of Kartli, a collection and redaction of earlier texts formed in the mid-eleventh century. The dates of Vakhtang's rule are disputed, but the most recent scholarship proposes the dates of 447 to $522 .{ }^{9}$ The Life of Kartli's description of Vakhtang's style of governing suggests that local elites in the Caucasus at this time received a Graeco-Roman education. This resulted in a specific understanding of good Christian rulership that will be at the heart of this examination. ${ }^{10}$

The surviving records, which certainly only deserve limited trust as sources, depict Vakhtang as a prudent politician, an energetic commander, a highly educated monarch with a great sense of responsibility, and a caring sovereign with a devout Christian disposition. Although the memory of Vakhtang remains quite vibrant within Georgia, knowledge of him, his time, and the long and dramatic historical developments in Georgia remain largely unknown in the West to this day. European scholars became aware of Georgia's history only at a relatively late date through the work of distinguished western scholars of the Caucasus and oriental studies. This study seeks to rectify this in part by bringing attention to the reception of one of the preeminent rulers of late antique Georgia within one of the most important medieval accounts of Georgian history.

7 On Persian religion and its manifold forms, see Michael Stausberg, Die Religion Zarathushtras. Geschichte - Gegenwart - Rituale, Stuttgart 2002-2004.

8 Heinz Fähnrich, Geschichte Georgiens (Handbook of Oriental Studies, Handbuch der Orientalistik, section eight, Central Asia 21), Leiden/Boston 2010, 122: "Der römische Kaiser Konstantin I. war der erste, der das Christentum in seinem Reich zur Staatsreligion erklärte. Dadurch wurde es in den politischen Kampf zwischen Rom und Persien einbezogen, und so erklärt es sich, daß die Perser nach der Annahme des Christentums durch Rom ihre Beziehung zu den Christen radikal änderten: Von der anfänglich wohlwollenden Duldung gingen sie zur gnadenlosen Verfolgung über.”

9 Stephen H. Rapp Jr., The Sasanian World through Georgian Eyes. Caucasia and the Iranian Commonwealth in Late Antique Georgian Literature, Farnham (Surrey) 2014, 271.

10 Vaxtang Goilaje, Vaxtang Gorgasali da misi istorikosi, Mecniereba, Tbilisi 1991; Sargis Kakabadze, Vaxtang Gorgasalis xana, Tbilisis Damoukidebeli Univ. [et. al.], Tbilisi 1994. 


\section{A Brief History of Scholarship on the Life of Kartli}

At the beginning of the nineteenth century, important tools for researching Vakhtang I were unavailable in the western hemisphere. The standard reference works of the time only provided incomplete information on the history of Georgia. Even the famous Conversations-Lexicon oder encyclopädisches Handwörterbuch für gebildete Stände published in 1815 was of no use. It merely devoted a couple of sentences to modern-age political development in Georgia; ${ }^{11}$ it contains no mention of Vakhtang I Gorgasali.

This state of affairs was first changed by Heinrich Julius Klaproth (1783-1835). In his Reise in den Kaukasus und nach Georgien unternommen in den Jahren 1807 und 1808 , the second volume of which was published in $1814,{ }^{12}$ he drew on abundant sources, compiled material on the kings of Georgia, and also included a profile of Vakhtang: $:^{13}$

After Mirdat (346), his son (...) Vachtang Gurg-aßlan, meaning Vachtang the Wolf-Lion ruled; as in Persian gurg means 'wolf' and aßlan means 'lion.' He possessed all royal virtues and is held by Georgians as one of their greatest princes. ${ }^{14}$

Unfortunately, Klaproth's remarks are largely confined to the political activities of the Georgian monarch and his many campaigns against hostile neighbours. In addition, he merely identified him as the founder of Tbilisi. According to his information, Vakhtang also built Christian churches and appointed the first "Catholicos of Georgia." ${ }^{15}$ Klaproth did not indicate that the basis of the monarch's politics was his intellectual disposition. Travel literature of the first half of the nineteenth century

11 Conversations-Lexicon oder encyclopädisches Handwörterbuch für gebildete Stände. Vierter Band. G und H. Leipzig/Altenburg ${ }^{3} 1815,167$.

12 Heinrich J. Klaproth, Reise in den Kaukasus und nach Georgien unternommen in den Jahren 1807 und 1808, auf Veranstaltung der Kaiserlichen Akademie der Wissenschaften zu St. Petersburg, enthaltend eine vollständige Beschreibung der Kaukasischen Länder und ihrer Bewohner, von Julius von Klaproth, Kaiserl. Russischem Hofrathe und Mitgliede der Akademie der Wissenschaften zu St. Petersburg. vol. 1, Halle/Berlin 1812; id., Reise in den Kaukasus und nach Georgien unternommen in den Jahren 1807 und 1808, auf Veranstaltung der Kaiserlichen Akademie der Wissenschaften zu St. Petersburg, enthaltend eine vollständige Beschreibung der Kaukasischen Länder und ihrer Bewohner, von Julius von Klaproth, Hofrathe und correspondirendem Mitgliede der königlichen Societät zu Göttingen. vol. 2, Halle/Berlin 1814.

13 Klaproth compiled this biography from various different materials: idem, Reise in den Kaukasus und nach Georgien II, 62.

14 Klaproth, Reise in den Kaukasus und nach Georgien II, 163: "XXXIII. Nach Mirdat (346) regierte dessen Sohn $\langle. .$.$\rangle Wachtang Gurg-aßlan, das ist Wachtang der Wolf-Löwe; denn im Persischen bedeu-$ tet gurg Wolf und a ßla n Löwe. Er besaß alle königlichen Tugenden und wird von den Georgiern für einen ihrer größten Fürsten gehalten.”

15 Ibid., 163-165. 
added little new information, ${ }^{16}$ and knowledge of Vakhtang's biography was not substantially expanded. ${ }^{17}$

This unsatisfactory situation remained until the French orientalist Marie Felicité Brosset (1802-1880) published his work on the history of Georgia from antiquity until 1469 in Saint Petersburg in $1849^{18}$ and dedicated it to Sergey Semionovich Uvarov (1786-1855), the president of The Saint Petersburg Imperial Academy of Sciences. ${ }^{19}$ Brosset took a Georgian source as his starting point and translated it into French. ${ }^{20}$ In an extensive preface he provided further details on the document, originally titled $K^{\prime}$ art'lis c'xovreba (Life of Kartli).

However, Brosset did not start from scratch in researching and translating the text. As he himself stated, he followed information contained in scholarly literature of the time. The Armenian Stefanos Orbelian (d. 1304) had already referenced this important text for the history of Georgia in a paper edited by the French orientalist Antoine-Jean Saint-Martin (1791-1832). ${ }^{21}$ At any rate, Brosset's translation was an achievement of great importance. For the first time, European scholars gained deeper insight into the history of Georgia. Translations into other languages were not available until much later. A German translation did not appear until 1985. ${ }^{22}$ An English translation and commentary have only been available to scholars since 2014, titled Kartlis tskhovreba: A History of Georgia. ${ }^{23}$ In its preface, the authors explicitly reference Brosset's accomplishment. ${ }^{24}$ Thus, with Brosset's translation, western scholars

16 Frédéric Dubois de Montpéreux, Reise um den Kaukasus, zu den Tscherkessen und Abchasen, nach Kolchis, Georgien, Armenien und in die Krim von Fr. Dubois de Montpéreux. Eine von der geographischen Gesellschaft zu Paris gekrönte Preisschrift. Nach dem Französischen. Erster Band. Mit zwölf Abbildungen, Darmstadt 1842 (original: ibid., Voyage autour du Caucase, chez les Tscherkesses et les Abkhases, en Colchide, en Géorgie, en Arménie et en Crimée, Paris 1839-1849).

17 Ibid., 263-264.

18 Marie Felicité Brosset, Histoire de la Géorgie depuis l'antiquité jusque'au XIX ${ }^{\mathrm{e}}$ siècle, traduite du géorgien par M. Brosset. Membre de l'Académie Impériale des Sciences. vol. 1, Histoire ancienne, jusqu'en 1469 de J.-C., St. Petersburg 1849.

19 Ibid.: “A Son Excellence Monsieur le Comte Ouvarof, Président de l’Académie Impériale des Sciences, Fondateur et Promoteur bienveillant des Études géorgiennes, en Russie; respectueux hommage de l'Editeur."

20 Ibid., 1-13 ("Préface. Aux Lecteurs, sur l'objet de ce livre”).

21 Ibid. (Préface), 1, fn. 1: "L’ouvrage que je traduis est connu en Géorgie sous le simple titre de kartlis zxovreba 'Vie du Karthli', titre qui était déjà donné au XIII siècle à une histoire de ce genre, puisque l'auteur arménien Stéfanos Orbélian le cite dans l'histoire de sa famille (S.-Martin, Mém. hist. et géogr. t. II., p. 64).”

22 Gertrud Pätsch, Das Leben Kartlis. Eine Chronik aus Georgien 300-1200 ("Dshuanscher. Das Leben Wachtang Gorgassals, des großen und gottliebenden Königs, der unter allen Königen Kartlis der berühmteste war”), Leipzig 1985, 201-322.

23 Roin Met'reveli, Stephen F. Jones, Kartlis tskhovreba. A History of Georgia ("Juansher Juansheriani, The Life of Vakht'ang Gorgasali”), 77-114, Notes p. 114-133), Tbilisi 2014.

24 Ibid., 6: "In 1849 the Russian Academy of Sciences published kartlis tskhovreba, based on the MS of the post-Vakht'ang period, edited by the French orientalist and Georgian Academician Marie-Féli- 
have been able to access an important document on the political and intellectual history of Georgia that does not merely devote a few words but rather a considerably large section to Vakhtang. ${ }^{25}$

The Life of Kartli contains some of the earliest records of Georgian history, including importantly some texts like the Life of Vakhtang Gorgasali that were composed before the founding of the Bagratid dynasty in 813. The author of these biographical writings is generally considered to have been Juanšer, ${ }^{26}$ who formed the ideal of a heroic, pious, and educated ruler found within. ${ }^{27}$ Due to the redaction of these works in the eleventh century, these pre-Bagratid works must be treated with much caution. The current state of research on the origin of the text has been concisely summarised by Stephen Rapp:

Building upon the meticulous analysis of Toumanoff, I have confirmed elsewhere that The Life of the Kings, The Life of Vakhtang Gorgasali and the latter's untitled continuation by Pseudo-Juanšer Juanšeriani attained their received forms just before Bagratid rule. All three texts proceed from the short interval between the establishment of the kingdom of Ap xazet i sometime in the last decade of the eighth century and the accession in 813 of the Bagratid Aŝot I to the presiding principate, the foremost political institution of the K'art velian interregnum (which began ca. 580).

Like almost all other medieval Georgian historiographies, these "pre-Bagratid" texts are preserved exclusively in K'art lis c'xovreba, "The Life of Georgia," the so-called Georgian Royal Annals or Georgian Chronicles. As we know today, the original iteration of the corpus was probably compiled under the direction of Archbishop Leonti Mroveli (Leontius of Ruisi) in the mid-eleventh century. This occurred during the zenith of medieval Bagratid power. Surviving manuscripts of $K^{\prime}$ art ${ }^{\circ} l i s c^{\prime}$ xovreba are relatively late: the oldest Georgian-language variant was copied towards the end of the fifteenth century. However, the oldest manuscript of its medieval Armenian adaption, Patmut iwn Vrac" ("The History of the Georgians"), belongs to the end of the thirteenth or start of the fourteenth century, a cosmopolitan period under İlkhānid hegemony. ${ }^{28}$

cité Brosset. Brosset translated the text into French and published it. He made this source on the history of Georgia accessible to the world community."

25 Pätsch (cf. fn. 22) 201-322; Kartlis tskhovreba (cf. fn. 23) 77-114, Notes 114-133)

26 Pätsch (cf. fn. 22) 322: "Dieses Buch aber vom Leben der Kartweler bis Wachtang wurde fortlaufend niedergeschrieben. Aber von König Wachtang bis jetzt hat es Dshuanscher aufgezeichnet, aus dem Geschlecht Dshuanschers, der Ehemann der Brudertochter des heiligen Artschil, der Nachkomme Rews, des Sohnes Mirians."

27 Ibid., 13: "Über das 5. bis 8. Jahrhundert berichtet Dschuanscher. Von ihm ist außer dem Namen nichts Sicheres bekannt. Im Mittelpunkt seiner Darstellung steht Wachtang Gorgassal, den er als das verkörperte Ideal des Heldenkönigs rühmt.”

28 Rapp (cf. fn. 9) 7-8; Stephen H. Rapp Jr., K'art'lis c' xovreba: The Georgian Royal Annals and Their Medieval Armenian Adaption (Anatolian and Caucasian Studies), Delmar (N.Y.) 1998; ibid., Studies in 
With due caution, this essay proceeds to investigate the representation of Vakhtang within the Life of Kartli to gain insight into the reception of this late antique king within the Georgian tradition.

\section{The Christianisation of Georgia according to the Life of Kartli}

The introduction of Christianity into Georgia was still quite recent when Vakhtang I became king. This section traces some of the major contours of the narrative of the Christianisation in Georgia in the Life of Kartli, including the traditional Georgian religion, the interventions of the Sasanians, and the measures of Georgian rulers to support Christianity. This will help contextualise the depiction of Vakhtang as a ruler within this work, as explored in the next section.

The traditional piety of the Georgians plays a role in the narrative of the Christianisation of Georgia in the Life of Kartli. The religious practices of Georgians remain admittedly opaque at the time of Christianisation, although it seems almost certain that they had a number of different gods. ${ }^{29}$ Several passing remarks in GraecoRoman literature suggest that several gods were worshipped in the Caucasus. Friedrich Creuzer (1771-1858), a leading romanticist mythologist of the first half of the nineteenth century, drew on these sources, writing about the gods of the Colchians focusing on Hecate, ${ }^{30}$ goddess of the underworld, ${ }^{31}$ and a moon goddess who allegedly demanded human sacrifice. ${ }^{32}$ The practices he described may have been those of the Greeks who had settled Phasis on the coast of Georgia early on. ${ }^{33}$ This was all the information Creuzer possessed as he did not have access to any original sources

Medieval Georgian Historiography. Early Texts and Eurasian Contexts (Corpus Scriptorum Christianorum Orientalium 601, Subsidia 113), Leuven, 2003.

29 Fähnrich (cf. fn. 8) 109-110; esp. 109: "Bis zum heutigen Tag besteht leider keine Klarheit über den Aufbau des altgeorgischen heidnischen Pantheons. Die Ansichten hierzu gehen weit auseinander. Aber unbestritten ist, daß die Georgier in vorchristlicher Zeit mehrere Götter verehrten.”

30 Thomas Lautwein, Hekate, die dunkle Göttin. Geschichte und Gegenwart, Rudolstadt 2009. For older mythologist literature on this goddess, see Eduard Gerhard, Griechische Mythologie. Erster Theil: Die griechischen Gottheiten, Berlin 1854, 573-576; Ludwig Preller, Griechische Mythologie. Erster Band. Theogonie und Goetter, Leipzig 1854, 199-201; Friedrich Gottlieb Welcker, Griechische Götterlehre. vol. 1, Göttingen 1857 (n. 91: 'Hekate') 562-567, (n. 92: 'Hekate Brimo') 568-570.

31 On the cult of Hecate in Phasis, see Otar Lordkipnanidze, Phasis. The river and city in Colchis (Geographica Historica 15), Stuttgart 2000, 97-98.

32 Friedrich Creuzer, Symbolik und Mythologie der alten Völker, besonders der Griechen. Vierter Theil. Dritte verb. Ausg. Leipzig/Darmstadt 1843 (ND Hildesheim/New York 1973), 235: “Jener (i.e., Aeetes U. R. J.) hat die schreckliche und zauberische Nachtgöttin, die weithintreffende Hecate, zur Tochter, die der Mondgöttin Artemis einen Altar stiftet, an welchem die anlandenden Fremdlinge als Opfer fallen müssen (Diod. IV. 45.).”

33 Cf. fn. 31. 
and had to rely on these reports. Such was the state of research on traditional Georgian piety before the translation of the Life of Kartli, which offers important insights into the local religious practices in Georgia. ${ }^{34}$ Before the translation of this work, Europeans knew very little about this topic.

In the Life of Kartli, the gods of Georgia are depicted much more clearly and prove to be numinous powers of a comprehensive nature-religion. Gods like Armas, ${ }^{35}$ Saden, ${ }^{36}$ Gazi, and Gaim ${ }^{37}$ are considered "Lords of the world," who "radiate the sun" and "send rains." As they "know all the secrets," they also have a spiritual dimension. According to the Life of Kartli, the gods cared for humans and were believed in by the people. ${ }^{38}$ Their followers erected anthropomorphic idols ${ }^{39}$ and offered sacrifices. ${ }^{40}$ Mtskheta, at the time capital of Kartli, stands out in literary texts as an important cult site at which the Georgians served their god Armaz. ${ }^{41}$

Within the Life of Kartli, the Sasanian Persians encounter these traditions during their attempts to integrate Kartli into their empire and establish Zoroastrianism there, resulting in inevitable religious differences with the indigenous Caucasians. The Georgians stand on one side with their local practices, the Persian Zoroastrians on the other. ${ }^{42}$ There are, according to the Life of Kartli, some similarities despite

34 More recent scholarship takes this source into account, see Georges Dumézil, Mythologie der kaukasischen Völker (Wörterbuch der Mythologie. I. Abt. Die alten Kulturvölker. 11. Lief.), Stuttgart 1973, $1-58$.

35 Dumézil (cf. fn. 34) 26: “Armaz. Höchste Gottheit, 'Gott der Götter’ im vorchristl. Georgien, sicher abgeleitet vom iran. Ahura-Mazda (armen. Aramazd). In der Vita der Hl. Nino wird gesagt, daß sein Bildnis, in Mtskhetha, Menschengestalt hatte, und zwar aus Kupfer, bekleidet mit einem goldenen Panzerhemd und einem Goldhelm und geschmückt mit kostbaren Onyx- und Beryll-Steinen. In der Hand trug er ein funkelndes Schwert. Diese Gottheit wird in allen alten georgischen Chroniken erwähnt. Der armen. Historiker Moses von Choren sagt, daß man A. bei Tagesanbruch verehrt habe.” 36 Ibid., 56: "Zaden. Eine Gottheit im vorchristl. Georgien, in mehreren Chroniken erwähnt, doch kennen wir fast nur seinen Namen. Im 'Leben der Hl. Nino' sagt König Mirian zur Heiligen: 'Es gibt die beiden Götter, die überreiche Ernten schenken und die Welt regieren; sie lassen die Sonne scheinen und lassen regnen, und so lassen sie, was die georgische Erde hervorbringt, wachsen: Armaz und Z., sie sehen alles Verborgene.' Der gleiche Text spricht von Opferungen erstgeborener Kinder an Armaz und Z. - Marr und Wesendonck haben den Namen mit dem pehlewischen Plural yaztān, persisch yazdān (vgl. avestisch yazata) 'Götter' erklären wollen. Tseretheli hat den asianischen Gott Sandon-Sandas mit ihm in Verbindung gebracht.”

37 Ibid., 32: “Ga (Gaim) und Gaci. Zwei Götter im vorchristl. Georgien, von denen wir wissen, dass sie in Mtsekhetha zwei Standbilder hatten, das eine aus Silber, das andere aus Gold, die links und rechts von einer Amazstatue aufgestellt waren. Die Vita der Hl. Nino bezeichnet sie als 'Königliche Götter' und erzählt, ein Fürstensohn sei ihnen zum Opfer gebracht worden. Für diese Namen wurden keinerlei annehmbare Erklärungen beigebracht.”

38 Kartlis tskhovreba. A History of Georgia (cf. fn. 23) 57, 12-14.

39 Ibid., 51.8-9.

40 Ibid., $49.28-29$.

41 Ibid., 50.25-26.

42 According to Hdt. 1.131.1, the Persians of his time did not tolerate temples, idols or altars, vehemently criticised their use, and condemned anthropomorphism. They called the circle of heaven Zeus 
these irreconcilable differences. As many Caucasians practice a purely nature-based cult, they do not find it difficult to worship fire. ${ }^{43}$ For example, Saint Nino (fourth century), upon reaching the town of Urbnisi, sees that fire, stones, and trees are held in high esteem as gods. ${ }^{44}$ Because the Persians want to establish a certain form of Zoroastrianism in Georgia, they find themselves forced to compromise. They draw on these similarities and occasionally permit the elites of Georgia to serve both the fire and their own gods. ${ }^{45}$

The local customs of Georgia trouble the Persians in the Life of Kartli but do not constitute a serious threat to their political aims. They seem more disturbed by the advance of Christianity into the Caucasus. This was not without reason. The local elites, who feared that the Persians intended to subjugate and integrate the Caucasus into their empire, searched for an alternative and turned towards Constantinople. Persia, which was closer geographically, seemed more dangerous. The Georgians preferred to adopt Christianity than the Persian religion, setting themselves firmly against Zoroastrianism. ${ }^{46}$

From this perspective, Mirian III's (r. 284-361) decision to recognise Christianity as the religion of Iberia in the 320s or 330s seems logical. ${ }^{47}$ Other Georgian kingdoms followed this decision. ${ }^{48}$ In the Life of Kartli, this monarch appears at first as an adherent of the traditional gods of Georgia and of the Zoroastrianism. ${ }^{49}$ He later turns his back on them, earning Constantine's favour. Georgians, however, ascribe his change of heart to Saint Nino, ${ }^{50}$ who won over the king to Christianity. ${ }^{51}$ Ultimately, only the political elite of Georgia could enforce the religious turn towards Christian-

and worshiped him on high mountains and also sacrificed to cosmic bodies such as the sun and the moon and the elements earth, fire water and air: Albert de Jong, Traditions of the Magi. Zoroastrianism in Greek and Latin Literature (Religions in the Graeco-Roman World 133), Leiden/New York/Cologne 1997, 76-120.

43 Kartlis tskhovreba. A History of Georgia (cf. fn. 23) 58.9-10.

44 Ibid., 50.21-23.

45 Ibid., 42.4-7.

46 Werner Seibt (ed.), Die Christianisierung des Kaukasus. The Christianization of Caucasus (Armenia, Georgia, Albania), Referate des Internationalen Symposions (Wien, 9.-12. Dezember 1999) (Österreichische Akademie der Wissenschaften, Philosophisch-Historische Klasse. Denkschriften 296 = Veröffentlichungen der Kommission für Byzantinistik 9), Vienna 2002.

47 On the proposals for dating the baptism of King Miriam III, see the summary in Rapp (cf. fn. 9) 3 n. 12.

48 Fähnrich (cf. fn. 8) 125: "Im westlichen Teil Georgiens verbreitete sich das Christentum etwa zur gleichen Zeit wie in Iberien und wurde zu Beginn des 4. Jahrhunderts zur offiziellen Religion des Königreichs Lasika."

49 Kartlis tskhovreba. A History of Georgia (cf. fn. 23) 58.9-14.

50 Ibid., 61.31.

51 Guliko Sophia Vashalomidze, Die Heilige Nino, in: id., Die Stellung der Frau im alten Georgien. Georgische Geschlechterverhältnisse insbesondere während der Sasanidenzeit (Orientalia Biblica et Christiana 16), Wiesbaden 2007, 48-78. 
ity; royal decisions were necessary. This can also be indirectly discerned from the Life of Kartli.

In the Life of Kartli, Christianity seems to irritate the Persians but does not cause them to doubt the superiority of their own tradition..$^{52}$ For this reason, many Sasanian kings intervene in the religious lives of Caucasians not only on account of their power-political interests, but also because they are convinced of the primacy and truth of their own religion. The strategies they pursue and means to which they resort are depicted in several poignant episodes in the Life of Kartli. In most cases the Persians favour force, ${ }^{53}$ but they occasionally rely on more subtle methods, trying to win over Georgians by means of political marriages, tolerance, and missionary conversion.

Initially, brute force, invasion, and suppression of the free exercise of religion seem the most promising paths to achieving their goal. For example, when the Georgian King Mirdat IV (r. 409-411) ${ }^{54}$ loses a battle to the Persians, they carry him off into exile where he later dies. Subsequently, they lay waste to Kartli, destroying Churches and repurposing some for Zoroastrianism. The inhabitants of Kartli are unfazed by this and continue to practice their faith in secret. ${ }^{55}$ Sometimes they even find enough strength for a counteroffensive. King Arč il I (r. 411-435), Mirdat IV's successor on the Georgian throne, revolts against the Persians, restores the Christian churches, and resists Zoroastrianism. ${ }^{56}$

Once brute force increasingly proves ineffective, the Persians try to break up the enemy front by means of blood ties between the Georgian and Persian elites. They find a sympathetic partner in Mirdat V (r. 435-447), the son of Arč il I, who does not continue the confrontational politics of his predecessors. Valiant and fearless, ${ }^{57}$ he takes measures to achieve peace and marries Sagduxt, ${ }^{58}$ the daughter of a highranking Persian official named Barzabod. The Georgian king expects this tactic to strengthen Christianity in Kartli, ${ }^{59}$ while the Persians probably hoped for greater influence on Georgian leadership.

52 On religion in the Sasanian Empire: Wiesehöfer (cf. fn. 1) 268-273; Richard E. Payne, A State of Mixture: Christians, Zoroastrians, and Iranian Political Culture in Late Antiquity (Transformation of the Classical Heritage 56), Oakland (California) 2015.

53 The obvious motive of this portrayal is to underline the Christians' courage in the face of Persian cruelty.

54 These and all subsequent dates concerning Georgian kings are according to Rapp (cf. fn. 9) 386387.

55 Kartlis tskhovreba. A History of Georgia (cf. fn. 23) 77.6-8.

56 Ibid., $77.13-16$.

57 Ibid., $78.3-4$.

58 On the origin of this name, see Ibid., 116, fn. 14.

59 The Life of Kartli features a fictional speech by Mirdat V to his father Arč il I in which he argues for peaceful coexistence between the inhabitants of Kartli and the Persians on account of his marriage to the daughter of a Persian aristocrat (Kartlis tskhovreba. A History of Georgia [cf. fn. 23], 78.14-20). 
In favourable circumstances, the Persians seek to appear tolerant. The aforementioned Georgian queen of Persian descent converts to Christianity and gives up Zoroastrianism influenced by her Christian husband and scholars. ${ }^{60}$ She fears acts of vengeance that could lead to the destruction of Kartli and the eradication of Christianity in Georgia. ${ }^{61}$ Therefore, she appeals to her father for forgiveness, which he generously grants. ${ }^{62}$ At the same time, her father acts shrewdly, as the Life of Kartli continues, and issues a surprising edict of toleration. No Georgian Christian would be compelled to abandon the Christian faith, but anyone who voluntarily decided in favour of the Persian religion should also be able to practice without restrictions. $^{63}$

The Persians in the Life of Kartli also make use of an additional measure supporting their politics: religious mission. In this regard, they send prominent representatives of Zoroastrianism to Georgia with the purpose of establishing the Persian religion in Mtskheta. ${ }^{64}$ They are partly successful at the beginning as the people, it is claimed, allow themselves to be convinced. However, the elites subsequently counteract this development successfully: Queen Sagduxt sends for a Christian priest from Byzantium and makes him bishop. The bishop with Byzantine roots combats the Persian religion so successfully that only a minority of Georgians remain loyal to Zoroastrianism. ${ }^{65}$ The missionary efforts of Persia in this way end in failure.

The Life of Kartli's narrative of the Christianisation of Georgia encompasses several elements that play a role in its subsequent depiction of Vakhtang I. These include the new possibility of education among the nobility, the attempts of Georgian rulers to situate themselves between the major political powers of Rome and Persia, and the attempts to navigate between traditional forms of piety, Christianity, and Zoroastrianism.

60 Kartlis tskhovreba. A History of Georgia (cf. fn. 23) 78.28-31.

61 Ibid., $79.18-21$.

62 Ibid., 79.25-28, 30-31.

63 Ibid., 79.31-34.

64 Ibid., 79.35-36.

65 Ibid., $79.40-80.8$. 


\section{The Image of Vakhtang I in the Life of Kartli}

In the Life of Kartli, Vakhtang I Gorgasali, ${ }^{66}$ the son of Mirdat V and Sagduxt, ${ }^{67}$ comes of age in the context of this tense situation and has a Christian upbringing. Since the Life of Kartli depicts him as an ideal ruler, its statements regarding his life cannot be taken at face value. Yet his depiction is significant for understanding the concept of good rulership at the time at which this work was authored and redacted. ${ }^{68}$ This section focuses on the religious and especially the philosophical elements of the depiction of Vakhtang's rule in the Life of Kartli in order to gain insight into the perspective on good rulership within this work.

According to the Life of Kartli, Vakhtang receives instruction from a Christian bishop. Through an education that was characterised by Christian spirituality, he then quickly develops into a staunch proponent of Christianity and a fierce opponent of Zoroastrianism. ${ }^{69}$ Already at a young age, he drafts policy guidelines and compiles them into a political platform, which he presents to the high nobility of Kartli and emphatically promotes. He promises the Georgian dignitaries unprecedented royal support, far exceeding that of his fathers. ${ }^{70}$ As the Life of Kartli suggests, Vakhtang keeps to his word, implementing his plans and cleverly gearing his politics towards the improvement of his subjects' situation.

The Life of Kartli does not only esteem Vakhtang's individual efforts towards ensuring safety for, strengthening, and consolidating Georgia. But it also attends to the remarkable king's inner disposition and mindset. Throughout, the image of a good ruler with Christian virtues is clearly visible. Vakhtang searches for inspiration within the Holy Scriptures, reveres the biblical Kings David and Solomon, and is guided by their pious actions. ${ }^{71}$ Vakhtang also regards Constantine the Great as his role model. The miracles, which the Roman emperor had witnessed through the power of the cross, become a source of inspiration for him. ${ }^{72}$ King Solomon and Constantine are also considered exemplary monarchs by his advisors, especially because they had

\footnotetext{
66 Vakhtang I witnessed many Persian and Roman/Byzantine monarchs. Late Roman/Byzantine emperors: Theodosius II (r. 408-450); Marcian (r. 450 - 457); Leo I (r. 457-474); Leo II (r. 474); Zeno (r. 474- 475 and 476 - 491); Basiliscus (r. 475-476); Anastasios I (r. 491-518); Justin I (r. 518 - 527). Persian monarchs: Yazdegerd II (r. 439-457); Hormizd III (r. 457-459); Peroz I (r. 459-484); Balash (r. 484488); Kavadh I (r. 488-496, 499-531). Dates of the Roman/Byzantine rulers according to Georg Ostrogorsky, Geschichte des byzantinischen Staates (Byzantinisches Handbuch I 2), Munich ${ }^{3} 1963,479$. For the Persian monarchs, see Wiesehöfer (cf. fn. 1) 409.

67 Kartlis tskhovreba. A History of Georgia (cf. fn. 23) 79.5-7.

68 On Vakhtang I, see Fähnrich (cf. fn. 8) 130-137.

69 Kartlis tskhovreba. A History of Georgia (cf. fn. 23) 80.27-30.

70 Ibid., 81.4-7.

71 Cf. fn. 73.

72 Kartlis tskhovreba. A History of Georgia (cf. fn. 23) 86.14-15.
} 
modelled their rule on the kingdom of heaven. ${ }^{73}$ According to the Life of Kartli, Christianity has a profound impact on the Georgian monarch's style of rule.

But the image of a good Christian ruler in the Life of Kartli importantly extends beyond his Christian faith and suggests that he received a philosophical education. For example, it reports that the Georgian king distinguishes himself by his wisdom early on. ${ }^{74}$ The biographer implies here that Vakhtang did not merely have worldly wisdom but also a knowledge of philosophy that complements his Christian disposition. If what his biographer later wrote in this section is true, then Vakhtang's tutors did not merely emphasise his religious education but also taught him philosophy.

This raises several difficult - perhaps unanswerable - questions. First, where might Vakhtang's knowledge of philosophy have come from? Byzantium seems the only likely possibility. ${ }^{75}$ Since late Roman emperors wanted to both win over Georgia to their side in their conflict with Persia and to cement their influence and safeguard their interests there, they intensified contacts with the Georgian elites, impressing the leading representatives of Georgia with the many advantages of Byzantine culture. This included not only late Roman/Byzantine Christianity, but also Christian philosophy, rooted in the philosophy of late antiquity.

Second, did Vakhtang himself participate in a school of thought that wanted to reconcile Plato and Aristotle from a Neoplatonic perspective? ${ }^{76}$ The answer to this question must remain a matter of speculation.

But, third, if it is true that Vakhtang learned philosophical ideas early on, is it possible to determine the specifics of what his educated advisors could have taught him about philosophy? This question seems possible to answer at least in regard to the depiction of the Georgian monarch in the Life of Kartli. His biographer explains the Georgian monarch's actions not only as coming from a purely Christian disposition, but also mentions philosophical motives for some of his political activities. According to the Life of Kartli, Vakhtang studied a philosophy that is not restricted to bookish speculation but embraces tangible philosophical praxis, ethics, and political philosophy.

Vakhtang's apparent philosophical education, though, can only be recognised by investigating a significant passage in the Life of Kartli. ${ }^{77}$ As will become apparent, no philosopher is actually named and an explicit reference to a specific philosophical background is also missing. But the text exhibits surprising similarities to some of Plato's propositions. This coincidence encourages comparison between Plato's thought and the reasoning attributed to Vakhtang in the Life of Kartli.

73 Ibid., 88.9-14.

74 Ibid. 80, 36: "The King began in a loud voice like a wise old man brought up among philosophers...."

75 Vakhtang was tutored by a cleric from Byzantium (cf. fn. 65 and 69).

76 Georgi Kapriev, Philosophie in Byzanz, Würzburg 2005.

77 Cf. fn. 88 and 91. 
According to the Politeia, Plato believed that leadership of a state was in the best possible hands if it was left to philosophers. ${ }^{78}$ Only if a thinker, chosen according to strict criteria, exercised power would there be justice in a polis. ${ }^{79}$ The arduous path from unsophisticated everyday knowledge to philosophical insight - from imprisonment in the cave to reality outside of the cave - and thus the constraints of the senses was described by Plato in the allegory of the cave. ${ }^{80}$ The way a comparable concept is depicted in the aforementioned passage - that is, the surprising speech attributed to Vakhtang in the Life of Kartli - will be investigated below.

First, however, it is necessary to examine the literary context of the speech. The Life of Kartli indicates that Vakhtang participates in wars as a vassal of the Persian King Peroz (r. 459-484). ${ }^{81}$ This includes a campaign in India on the eastern border of the Persian Empire. ${ }^{82}$ The expedition is successful. At the order of the Persians, Vakhtang turns against the Sindhs and lays siege to their capital..$^{83}$ An interesting encounter allegedly takes place there, when the king of the Sindhs tries to persuade the Georgian king to leave the Persians and join him. ${ }^{84}$ As weapons are of no use he resorts to rhetoric, presenting a fable (according to Pätsch) or parable (according to Brosset) to Vakhtang. He employs the image of a crow encountering a wounded hawk. Contrary to expectation, the crow does not call on other crows in order to destroy it with their help but rather takes pity on the hawk and nurtures it. Later, the hawk eats the crow by way of thanks. This fable of the beast is meant to make Vakhtang, the vassal of the Persians, reconsider and to provoke a political about face.

The king of the Sindhs argues from a purely strategic standpoint. The Persians are currently in a state of weakness - why else would they need Vakhtang's support? The time is right for revolt, as the minor adversaries of Persia can destroy their empire together. Vakhtang is merely strengthening the Persians as their dutiful vassal. But as soon as the Persians overcome their weakness with his help, they will destroy

78 Pl. resp., 7.514a-518b (allegory of the cave); Platons Höhlengleichnis. Das Siebte Buch der Politeia. Griechisch/Deutsch. Ed. and trans. by Rudolf Rehn, Mainz 2005.

79 Rosamond Kent Sprague, Plato's Philosopher-King. A Study of the Theoretical Background, Columbia 1976; Michael Erler, Platon (Die Philosophie der Antike, vol. 2/2 = Grundriss der Geschichte der Philosophie), Basel 2007, 441-449 ('Politische Philosophie'), esp. 445 - 446 (Lit. 710 - 712).

80 Hans Lier, Zur Struktur des platonischen Höhlengleichnisses, in: Hermes 99 (1971), 209 - 216; Konrad Gaiser, Il paragone della caverna. Variazioni da Platone a oggi, Napoli 1985; Hans Blumenberg, Höhlenausgänge, Frankfurt a.M. 1989; Wilhelm Blum, Höhlengleichnisse. Thema mit Variationen, Bielefeld 2004.

81 Kartlis tskhovreba. A History of Georgia (cf. fn. 23) 98.16-101.28.

82 Ibid., $98.18-24$.

83 Ibid., 98.25-99.9.

84 "Sindh" must be a region of the Indian subcontinent close to Persia, see Leopold von Orlich, Indien und seine Regierung. Geschichte und Colonisation der Länder Sind und Peng'âb, Geschichte des Königreichs Oude und Schilderung der britisch-indischen Armee. Nach den vorzüglichsten Quellen und nach Handschriften, vol. 2, Berlin 1859, ('Geschichte des Sind vom Jahr 600 bis zum Jahre 1857'), 2. 
the Georgians. ${ }^{85}$ The strategy of the king of the Sindhs is a calculus of power politics. Vakhtang's biographer likely tried to communicate this by including this fictional appeal. The fable of the king of the Sindhs with his unprincipled actions serves as a foil to Vakhtang, the Christian king with a philosophical mindset. ${ }^{86}$

According to the Life of Kartli, Vakhtang does not engage in risky endeavours. Thus, he categorically declines the offer of the king of the Sindhs to conspire against the Persians. ${ }^{87}$ His response is also indicative of other principles of royal action, such as when Vakhtang accuses the Sindh of profound untruthfulness. Although his assertions seem to be true, they are ultimately based on lies. The real truth looks different.

Vakhtang also turns to a fable to rebuke the king of the Sindhs. From his perspective, the king of the Sindhs resembles a blind mole living underground. As mentioned above, Vakhtang here is alluding to the cave dwellers of Plato's allegory in the politeia, who live as chained prisoners. All they can see are shadows that they believe to be reality. They know nothing of the real world outside and therefore are not aware of the sun, the "form of the good." For this reason, they think that everything that exists is exactly as they perceive it. They do not even wish to leave their cave and resist leaving. If they must step outside, they immediately endeavour to return to their seclusion. The path to wisdom, truth, and unconcealment remains barred to them.

To Vakhtang, the king of the Sindhs is in a similar situation to the mole, who as a cave dweller is only aware of his underground corridors, cannot see the sun, and knows nothing of the beauty of the fields on the surface above his burrow. He remains in a limited underground existence that befits him, and he therefore believes everything exists just as he does. He neither strives towards the light nor wishes to perceive the heavens or the earth, meaning he does not desire to find the cave's exit:

Then Vakht'ang said: "You think that your speech was inspired by the eye of wisdom. But your words are false. I will tell you the truth. You are mad! You resemble a mole, devoid of eyes which lives underground and knows nothing of the brightness of the sun and the fascinations of space, who is content with his life, because he thinks that all living things live like that. And he does not want to see the light and all the charms of heaven and the earth." 88

In this passage from the Life of Kartli, Vakhtang seems inspired by Plato, who as noted above thinks of the average human who has no philosophical inclinations

85 Kartlis tskhovreba. A History of Georgia (cf. fn. 23) 99.10-100.2.

86 Pätsch (cf. fn. 22) 47: "Bei Dshuanscher stammt die Parabel von der Krähe aus der alten indischen Sammlung 'Kalilah und Dimnah.' Bei den im Titel genannten Erzählern handelt es sich um zwei Schakale, die ihre Weisheit in der Form von Geschichten austauschen. Und es fällt dem Chronisten nicht schwer, in der Antwort Wachtang Gorgassals Stil und Stimmung beizubehalten” (Husain al-Kerbala'-I, Kalilah und Dimnah. Orientalische Fabeln. Mit zehn alten orientalischen Miniaturen, Leipzig 1974, 47).

87 Kartlis tskhovreba. A History of Georgia (cf. fn. 23) 100.3-101.28.

88 Kartlis tskhovreba. A History of Georgia (cf. fn. 23) 100.3-7. 
as a deluded cave dweller, lacking knowledge of the truth of the forms and chained to shadowy illusions instead of authentic truths. Vakhtang perceives the king of the Sindhs as likewise trapped in ignorance. He does not truly see what he sees or truly hear what he hears. Instead of living in unconcealment, he exists in concealment in a superficial semblance of the sensory world.

The intellectual world - the forms in Plato - remains hidden to the king of the Sindhs, because he does not pursue this extrasensory, transcendental world, grounded in the eternal form of the good. ${ }^{89}$ Instead, he clings to the sensory, holds on to the transient, and invests in finite interests. Therefore, he knows nothing of "infinite life" and the "light" which Vakhtang describes as not merely "eternal" but being of a "greatness that is unspeakable and inconceivable." 90 In this passage, Vakhtang states:

So are you blind in the eyes of your mind and deaf to the reason of your ears. You do not see or hear, or even know anything of the spiritual life; and you do not want to enter the everlasting, bright and infinite life, the greatness that is unspeakable and inconceivable. And you know nothing of the Lord, the maker of all beings, creator of everything. ${ }^{91}$

Here Plato's "form of the good" and Vakhtang's Christian God, the "creator of all things," converge.

This is the perspective from which Vakhtang confronts the political ambitions of the king of the Sindhs, ever conscious of the eternal. In doing so, he comports himself in a manner worthy of a philosopher king who is mindful of the good, as is demanded by both Plato and Christianity. Vakhtang's campaign on his view is not about finite interests or power politics. He thinks of himself not as the vassal of the Persian king but rather as a servant of the everlasting God, the God of Christianity, whom he describes as the "consubstantial Trinity," the "maker of the world," and "glory, for ever and ever." 92 According to this account, Vakhtang's politics draw their strength from the maxims of a Christian philosophy that oblige him to act ethically. He fulfils these principles in an exemplary manner. According to the Life of Kartli, he is protecting the Holy Jerusalem and saving all of Christendom from being destroyed by the Persian king. ${ }^{93}$

89 Rafael Ferber, Platos Idee des Guten, Sankt Augustin ${ }^{3} 2015$.

90 Neoplatonic Theology argues in a similar vein, see Jens Halfwassen, Der Aufstieg zum Einen. Untersuchungen zu Platon und Plotin, Munich/Leipzig ${ }^{2} 2006$.

91 Kartlis tskhovreba. A History of Georgia (cf. fn. 23) 100.8-11.

92 On the dogmatics of early Georgian Christianity, see K. Kekelidze, Geschichte der kirchlichen georgischen Literatur. Auf Grund des ersten Bandes der georgischen Literaturgeschichte v. K. Kekelidze ed. by P. Michael Tarchnišvili and Julius Assfalg (Studi e testi 185), Vatican City 1955; Wolfgang Hage, Das orientalische Christentum (Die Religionen der Menschheit 29,2), Stuttgart 2007, 112-126 ('Die Georgisch-Orthodoxe Kirche').

93 Kartlis tskhovreba. A History of Georgia (cf. fn. 23) 100.12-16. 
In this account, Vakhtang accomplishes what the Byzantines were not able to on account of political weakness. He protects his own kingdom aided by the "power of Christ" and military means. He thereby conforms to his fundamental disposition as a Christian king, who is mindful of the good, puts his hope in Christ, and proves himself by his efforts on behalf of his (Christian) neighbours. In this vein, Vakhtang interprets his campaign in India in the retinue of the Persian king as salvation and as a sacrifice for the forgiveness of his sins. In addition, he sees himself as the protector of Christianity against the Persians. ${ }^{94}$

But why support the Persians in the first place? Vakhtang also has a reasonable explanation for this conduct, seemingly opposed to the interests of Georgia. He first references his kinship with the Persians and then proceeds to a religious rationale. While the Persians may not acknowledge the Christian faith, they do believe in both a "creator" and a "spiritual being." The Sindhs are, by their ignorance, much further removed from true understanding. ${ }^{95}$

In the Life of Kartli, Vakhtang labels the world view of the Sindhs as "disgusting" and lacking any moral value from a Christian point of view. Contrary to human nature, they praise those who betray and destroy their benefactors without loyalty. According to Vakhtang's understanding of Christianity, one should treat benefactors in a charitable way. For this, one will receive the praise and recognition from humanity in this life and the forgiveness and eternal life from God in the next. Whoever dies a martyr's death shall even become immortal. ${ }^{96}$

This episode in the Life of Kartli reveals the work's depiction of Vakhtang as a good ruler based both on his Christian commitments and his philosophical outlook. The subtle allusions to Plato's allegory of the cave show how a philosophical background became woven into the concept of good Christian rulership in this work. While it is difficult to say how far back these ideas may go in Georgian history, they at least offer insight into the reception of Vakhtang in the Georgian tradition and the importance placed on philosophy in the concept of good rulership within the Life of Kartli.

\section{Conclusion}

This study has focused on episodes in the Life of Kartli that reveal views on good Christian rulership centred on the figure of Vakhtang I Gorgasali. This work reflects the perspectives of a time well after Vakhtang himself ruled, and its history of redaction separates us even further from the world of late antiquity. It nevertheless offers

94 Ibid., 100.17-23.

95 Ibid., 100.24-28.

96 Ibid., 100.29-33. 
insight into the representation of good rulership in Georgia within the Georgian chronicles.

Vakhtang's depiction within this work can be summarised as follows. According to the Life of Kartli, the Georgian King Vakhtang I grew up in a world of Roman-Persian tensions and distinguished himself as a Christian ruler, who had to come to terms with the non-Christian ruler of Persia. He received a Christian education that recommended David, Solomon and Constantine as political role models. He is seen as a promoter and saviour of Christianity, who feels deeply obliged to Christian ethics. And, most interesting for the depiction of good Christian rulership in this work, Vakhtang's thoughts and deeds seem influenced by philosophical thinking. In a fictional speech put into his mouth by his biographer, Vakhtang commits to the "form of the good" and aspires to an ideal approaching a platonic philosopher king.

How far the portrayal of Vakhtang in this work corresponds to historical fact is another matter. ${ }^{97}$ This paper has sought to shed light on how the Life of Kartli - composed and redacted well after his reign - highlights the philosophical reasoning of Vakhtang, one of the preeminent rulers of the Georgian past. In this way, an emphasis on philosophical expertise was woven into one concept of good rulership that developed in medieval Georgia.

97 Stephen H. Rapp, New Perspectives on 'The Land of Heroes and Giants'. The Georgian Sources for Sasanian History, in: E-Sasanika 13 (2014), 1-32. 
